\title{
Building ceramics based on composition of low- quality clay and slurry
}

\author{
Viktoriya Guryeva ${ }^{1, *}$, Alexander Doroshin ${ }^{1}$, and Yuliya Andreeva ${ }^{1}$ \\ ${ }^{1}$ Orenburg State University, 460018 Orenburg, Russia
}

\begin{abstract}
At present, there is a trend towards increasing demand for ceramic products with enhanced physical and mechanical properties. This study is aimed at developing scientifically grounded compositions of ceramic products that maximize the use of local low-quality aluminosilicate raw materials and secondary raw materials in brick-making technology. Characteristics of local low-melting clays and industrial waste in the form of drilling slurry with minimum percentage of petroleum product were studied and presented in this paper. Standard methods for determining physical and mechanical properties of bricks, physicochemical and statistical methods of research are used as a methodological framework. The paper shows effects of drilling slurry with an increased content of calcium oxide on the composition, physical and mechanical properties of wall ceramics, as well as effects of composition of lowquality local clays and slurries on the structure and properties of ceramic materials. The modifying role of container glass and its effects on properties of a synthesized ceramic piece were studied and presented.
\end{abstract}

\section{Introduction}

Priority objectives for the building materials industry, including manufacturers of building ceramics, are to improve energy efficiency of production and to reduce the ecological footprint of industrial products. Currently, clays are one of the main components of ceramic products around the world. However, despite the presence of basic minerals in the composition of aluminosilicate raw materials, each clay deposit has its own features. These differences arise from conditions of deposit formation in different geological periods, mineralogical and chemical compositions, thickness of accumulations of useful raw materials and overburdens [1]. Most of local argillaceous rocks around the world are lowmelting. Rock forming minerals are represented by mixed layered hydromicamontmorillonite formations. Disadvantages of these clays are a narrow sintering range and low fire resistance. A ceramic piece is characterized by high water absorption capacity and loose structure due to high content of carbonate inclusions, silt and sand.

Use of industrial waste in production seems to be a promising solution for improving the quality of building ceramics based on low-melting clays [2]. In developed countries such as the United States and Germany, the percentage of recycled waste has exceeded $30 \%$

*Corresponding author: victoria-gurieva@mail.ru 
[3]. According to a literature review, ceramic products with a spatially organized structure are found to have been produced on the basis of industrial waste [4]. A promising solution is to produce composite ceramic materials on the basis of their modeled structure by optimizing material and fractional compositions of a batch and industrial filler, as well as by achieving the maximum packing density in a semi-finished product [4]. Russian and foreign scientists, such as A. Yu. Stolboushkin, V. N. Makarova, R. Socolar, P. Raut, et al. [2-8] show that various kinds of industrial products can be used as raw materials in production of high-quality wall ceramics.

However, a diverse range of mineralogical and chemical compositions of industrial products, poorly studied raw materials and batch compositions during heat treatment limits their use in the production of building materials. The literature review shows that the use of drilling slurries as raw materials in ceramic products has not been studied yet. Therefore, the authors carried out this study to develop building ceramics products based on scientifically grounded compositions in low-temperature firing conditions with the aim of improving the quality of ceramic products, maximizing the use of locally extracted raw materials, and introducing secondary raw materials in industrial production. The object of the study is a ceramic brick based on low-quality clay and drilling slurry with high calcium content. The scope of the study is phase and structure formation processes, as well as properties of a synthesized composite ceramic material.

\section{Materials and Methods}

The initial aluminosilicate raw materials are represented by low-melting clays from the Buzuluk deposit in the northwest of the Orenburg Region and the Alimsay deposit located on the southeastern margin of Orenburg (capital city of the Orenburg Region), Russia. A previously unexplored drilling slurry of Orenburgneft PJSC was chosen as an additive due to the proximity and availability of this source [7].

The methodological framework of the study includes standard methods for determining chemical, particle-size and mineralogical compositions, physicochemical methods for determining the phase composition of samples (X-ray diffraction analysis, differential thermal analysis), optical microscopy methods, methods for determining physical and mechanical properties of ceramics, and statistical methods for planning and processing experimental data.

Raw materials, molding compounds with moisture content of $8-10 \%$ and samples were prepared according to the standard procedure adopted in ceramic production. The samples were molded in the form of cylinders with a diameter of $50 \mathrm{~mm}$. They were dried at $100{ }^{\circ} \mathrm{C}$ for 12 hours to constant weight. Then they were fired in the range of 900 to $1,100{ }^{\circ} \mathrm{C}$ at a heating rate of $5{ }^{\circ} \mathrm{C} / \mathrm{min}$ and held at the maximum temperature for 60 minutes.

\section{Results}

At the first stage of the study, chemical and particle-size compositions of the test clays were determined (Tables 1, 2).

Table 1. Chemical composition of test clays.

\begin{tabular}{|c|c|c|c|c|c|c|c|c|c|c|c|}
\hline \multicolumn{10}{|c|}{ Oxide content, \% on a dry matter basis } \\
\hline Deposit & $\mathrm{SiO}_{2}$ & $\mathrm{TiO}_{2}$ & $\mathrm{Al}_{2} \mathrm{O}_{3}$ & $\mathrm{Fe}_{2} \mathrm{O}_{3}$ & $\mathrm{MnO}$ & $\mathrm{CaO}$ & $\mathrm{MgO}$ & $\mathrm{Na}_{2} \mathrm{O}$ & $\mathrm{K}_{2} \mathrm{O}$ & $\mathrm{P}_{2} \mathrm{O}_{5}$ & $\begin{array}{c}\text { loss on } \\
\text { ignition }\end{array}$ \\
\hline Buzuluk & 41.71 & 0.23 & 3.92 & 2.10 & 0.01 & 25.6 & 0.37 & 0.18 & 0.94 & 0.12 & 23.05 \\
\hline Alimsay & 56.50 & 0.67 & 12.75 & 4.78 & 0.01 & 9.27 & 2.75 & 1.1 & 1.84 & 0.6 & 10.47 \\
\hline
\end{tabular}


Table 2. Particle-size compositions.

\begin{tabular}{|l|c|c|c|c|c|}
\hline \multirow{2}{*}{ Clay deposit } & \multicolumn{5}{|c|}{ Particle size, mm / Size frequency, \%, } \\
\cline { 2 - 6 } & $1.0-0.063$ & $0.063-0.01$ & $0.01-0.005$ & $0.005-0.001$ & $<0.001$ \\
\hline Buzuluk & 14 & 10 & 1 & 6 & 42 \\
\hline Alimsay & 4 & 32 & 12 & 14 & 38 \\
\hline
\end{tabular}

The mineralogical composition of the clays was determined by petrographic and X-ray diffraction analyses. The data are given in Table 3.

Table 3. Mineralogical composition of the clay from the Buzuluk deposit.

\begin{tabular}{|c|c|c|c|c|c|c|}
\hline \multirow{2}{*}{ Quartz } & \multicolumn{2}{|c|}{ Feldspars } & \multicolumn{2}{c|}{ Mica and hydrous mica } & \multicolumn{2}{c|}{ Carbonate minerals } \\
\cline { 2 - 7 } & Albite & Microcline & Muscovite & Chlorite & Calcite & Dolomite \\
\hline 32.8 & 17.5 & 5.3 & 8.1 & 7.5 & 25.4 & 4.0 \\
\hline
\end{tabular}

The obtained data indicate that both clays are sandy, which agrees with the data in Table 2. According to the X-ray diffraction analysis, particles larger than $10 \mu \mathrm{m}$ are represented by primary minerals such as quartz, feldspar and mica. Particles less than $5 \mu \mathrm{m}$ are composed of argillaceous materials, mostly of hydromica-montmorillonite formations. The clay from the Buzuluk deposit is characterized by a high content of carbonate compounds represented by limestone and dolomite, with a particle size of 5-10 $\mu \mathrm{m}$ and more. In terms of clay particles (less than $5 \mu \mathrm{m}$ ) and dust / sand particles (more than $5 \mu \mathrm{m}$ ), the tested aluminosilicate raw material belongs to the group of clays. The low alumina content, especially in the clay from the Buzuluk deposit, indicates low fire resistance of clays and sintering temperature.

In order to determine properties of the aluminosilicate raw materials, we tested laboratory samples using standard techniques subject to the requirements of [8]. At the first stage, the main pre-firing properties of clays (Table 4) were studied. These properties determine the choice of the most appropriate method for molding products and preparing molding compounds.

Table 4. Pre-firing properties of raw materials for ceramic products.

\begin{tabular}{|l|c|c|c|c|}
\hline Deposit & $\begin{array}{c}\text { Plasticity index } \\
\text { (PI, \%) }\end{array}$ & $\begin{array}{c}\text { Molding- } \\
\text { moisture } \\
\text { content } \\
\%\end{array}$ & $\begin{array}{c}\text { Air } \\
\text { shrinkage, } \\
\%\end{array}$ & $\begin{array}{c}\text { Coefficient of } \\
\text { drying sensitivity }\end{array}$ \\
\hline Buzuluk & 24.01 & 24.01 & 4.4 & 0.82 \\
\hline Alimsay & 24.4 & 24.9 & 10.8 & 1.93 \\
\hline
\end{tabular}

The obtained results show that the test clays are classified, respectively, as clays of moderate and medium plasticity in terms of the plasticity index; as clays of low and high sensitivity in terms of the coefficient of drying sensitivity. Firing properties of the clays were determined within a range of 900 to $1150^{\circ} \mathrm{C}$. (Fig. 1, 2) 


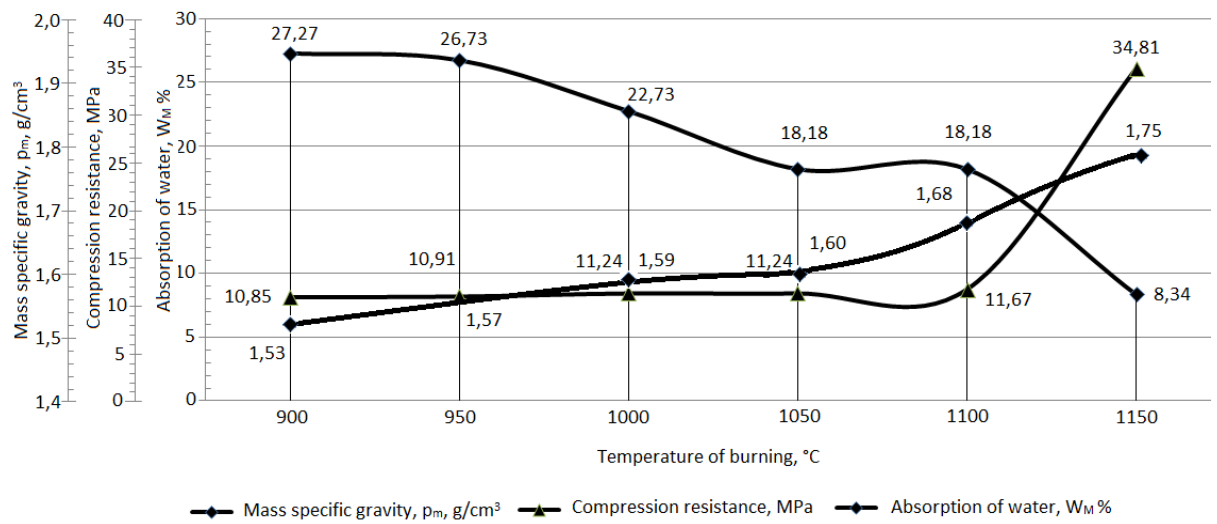

Fig. 1. Firing properties of the clay from the Buzuluk deposit, Orenburg Region.

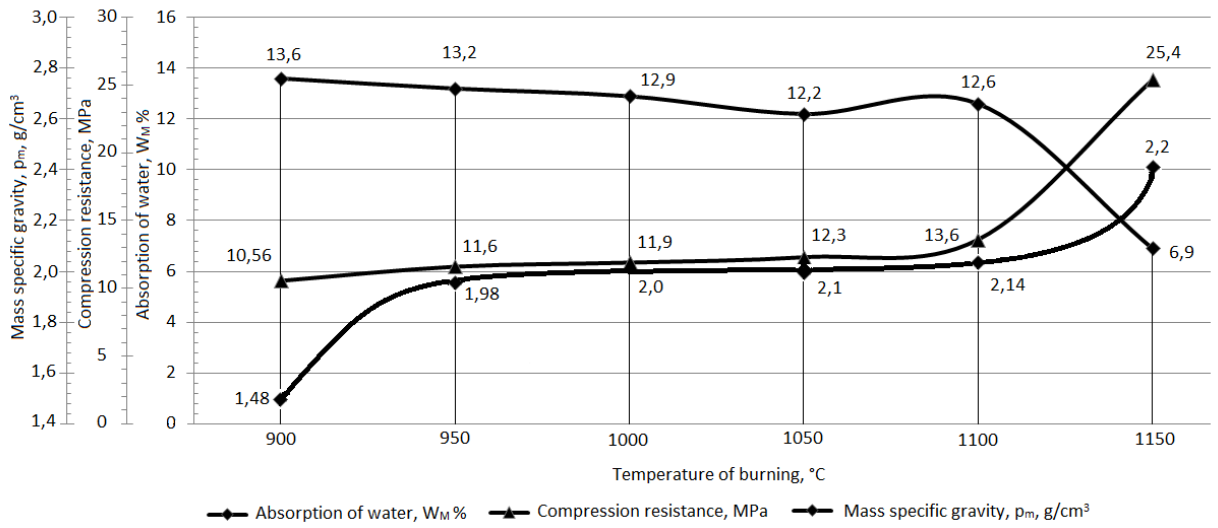

Fig. 2. Firing properties of the clay from the Alimsay deposit, Orenburg Region.

As it can be seen from the graphs, both clays demonstrate a decrease in water absorption to the limit specified in [9] and, at the same time, an increase in strength in a temperature range of 1,100 to $1,150{ }^{\circ} \mathrm{C}$. Since the water absorption of the clays in the tested temperature range exceeds $5 \%$, it can be concluded that the fired clays form a piece which is difficult to sinter. The obtained data suggest that the test low-quality clays can be used in the production of ceramic products in combination with corrective additives that affect physical and mechanical properties of products in accordance with applicable standards.

In further research, the clay of the Buzuluk deposit was used as the basic low-quality aluminosilicate raw material.

The material composition of the disposed slurry was analyzed according to the data of Orenburgneft PJSC. The results show that the content of petroleum products in the slurry ranges from 800 to $9,870 \mathrm{mg} / \mathrm{kg}$. In samples of asphalt, resin, and paraffin deposits taken from pits of oilfields in the Southern Urals, the content of paraffin and ceresin components with melting points of $66-84{ }^{\circ} \mathrm{C}$ is $40-70 \%$ by weight. The content of the organic part is $72-90 \%$ by weight. [11]. In the experimental part, drilling slurry with a minimum percentage of petroleum product was used. The chemical composition is shown in Table 5. 
Table 5. Chemical composition of the samples taken from the mineral constituent of slurry.

\begin{tabular}{|c|c|c|c|c|c|c|c|c|c|}
\hline \multirow{2}{*}{ Name } & $\mathrm{SiO}_{2}$ & $\mathrm{Fe}_{2} \mathrm{O}_{3}$ & $\mathrm{CaO}$ & $\mathrm{MgO}$ & $\mathrm{SO}_{3}$ & $\mathrm{R}_{2} \mathrm{O}$ & $\mathrm{Al}_{2} \mathrm{O}_{3}$ & $\begin{array}{c}\text { loss on } \\
\text { ignition }\end{array}$ & $\sum$ \\
\hline $\begin{array}{c}\text { Slurry } \\
\text { from fields } \\
\text { of Orenburgneft } \\
\text { PJSC }\end{array}$ & 23.84 & 10.8 & 21.28 & 2.28 & 1.81 & 10.83 & 3.72 & 29.24 & 100.0 \\
\hline
\end{tabular}

The comparison between chemical compositions of drilling slurries from various slurry pits in the Russian Federation shows that they are similar to each other. At the same time, secondary raw materials in all regions have significant fluctuations in chemical and mineralogical compositions, even if they come from the same slurry pit. The test slurry is featured by increased carbonate content. Therefore, theoretical and experimental studies of raw materials are required to determine the possibility of using it in ceramics engineering.

In order to use drilling slurry as a component of ceramic compound, its sinterability should be taken into account as an important parameter. For this reason, sinterability of the slurry was assessed at the first stage on the basis of firing properties. The average density of the slurry increases with temperature and, at $\mathrm{t}=1,150{ }^{\circ} \mathrm{C}$, reach $1.22 \mathrm{~g} / \mathrm{cm}^{3}$ (Fig. 3). Water absorption in the firing range of $900{ }^{\circ} \mathrm{C}$ to $1,150{ }^{\circ} \mathrm{C}$ decreases by $57.7 \%$ and reaches $19.2 \%$ (Fig. 4).

Shrinkage was not determined due to lack of plasticity. Since the fire resistance of slurry particles exceeds $1,200{ }^{\circ} \mathrm{C}$, the experimental temperature range did not allow us to reach the required sinterability of the material. The fired slurry samples were characterized by low compressive strength.

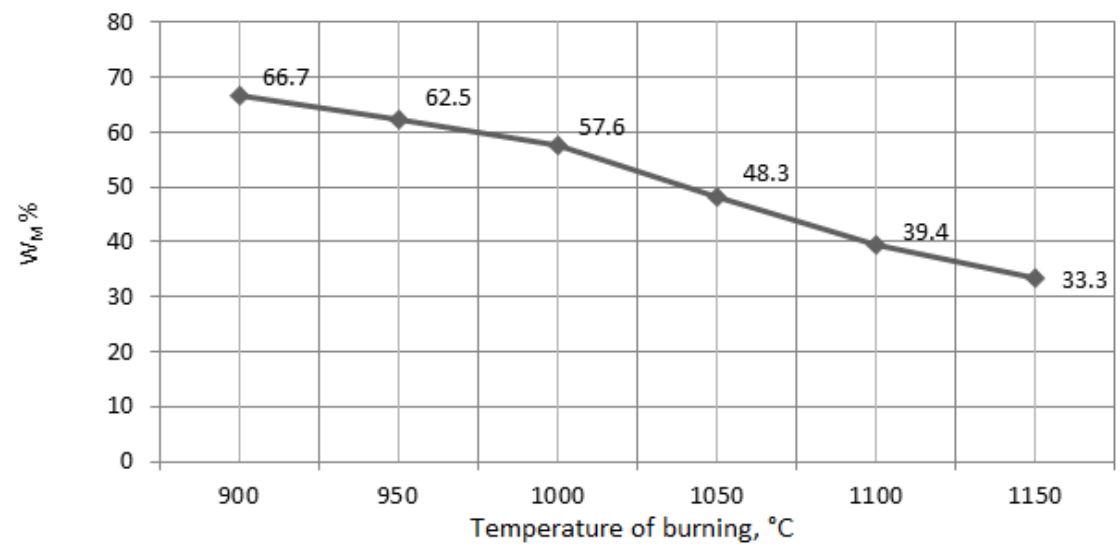

Fig. 3. Average density of the slurry. 


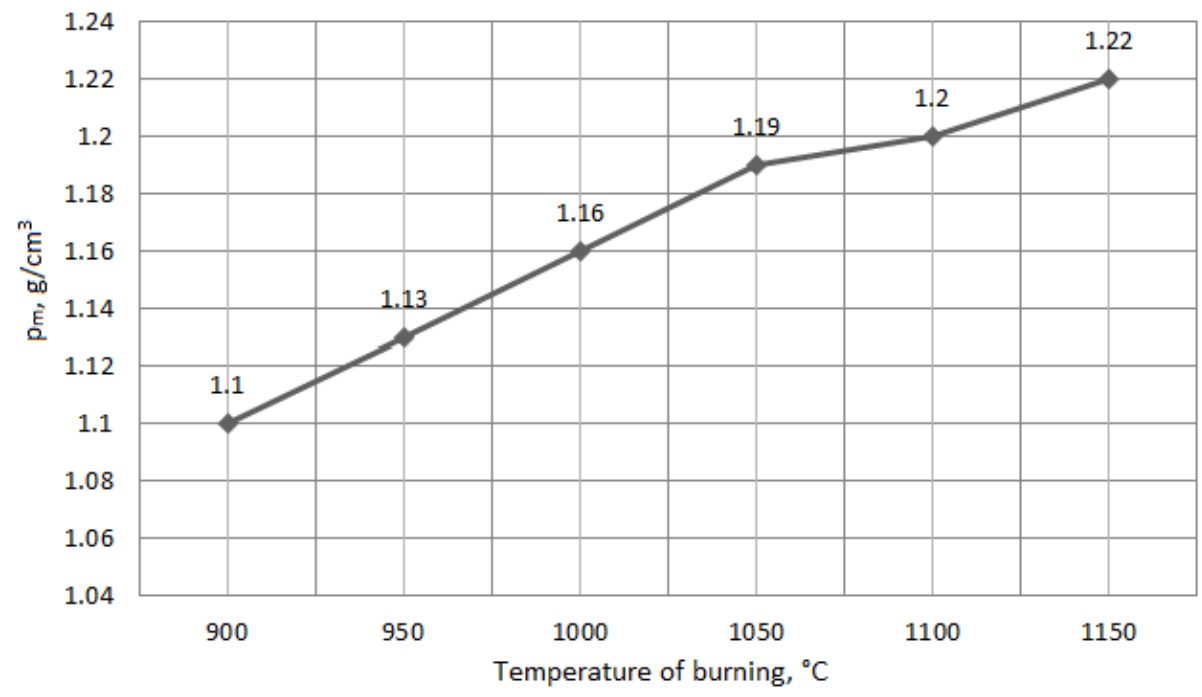

Fig. 4. Water absorption of the slurry.

Due to the fact that the previous experiments indicate low sinterability of the drilling slurry taken in bulk from a landfill, it is necessary to increase the temperature of burning as in the case of low-melting raw materials - within $1,050-1,200{ }^{\circ} \mathrm{C}$, in order to achieve satisfactory mechanical results [8]. However, this technological solution will inevitably lead to higher energy costs and higher cost of production. To solve this problem, and increase the density and strength of the synthesized artificial composite stone, we decided to add an additional additive, sintering aid (flux), to a batch [10].

The most common type of a flux is cullet, which has a low melting eutectic and initiates the formation of a liquid phase in the ceramic structure. Part of the melt formed during firing is used to fill large pores and coat grains of the material, acting as a binder between ceramic particles [14]. In a cullet production experiment, container glass was used according to GOST 54170-2010. Its chemical composition is presented in Table 6.

Table 6. Chemical position of container glass.

\begin{tabular}{|c|c|c|c|c|c|c|c|c|c|}
\hline \multirow{2}{*}{ Name } & \multicolumn{8}{|c|}{ Chemical composition, \% } \\
\cline { 2 - 9 } & $\mathrm{SiO}_{2}$ & $\mathrm{Al}_{2} \mathrm{O}_{3}$ & $\mathrm{Fe}_{2} \mathrm{O}_{3}$ & $\mathrm{CaO}$ & $\mathrm{MgO}$ & $\mathrm{Na}_{2} \mathrm{O}$ & $\mathrm{K}_{2} \mathrm{O}$ & $\begin{array}{c}\text { loss on } \\
\text { ignition }\end{array}$ & $\sum$ \\
\hline $\begin{array}{c}\text { Container } \\
\text { glass }\end{array}$ & 67.40 & 5.81 & 1.76 & 7.21 & 3.38 & 12.73 & 2.0 & - & 100.02 \\
\hline
\end{tabular}

In order to optimize the batch composition depending on the compound and firing conditions [10], we developed compounds of the three-component system "clay - slurry cullet" (Table 7). Prior to batching, the container glass was coarsely ground to a particle size of $1.0 \mathrm{~mm}$ and then finely ground to a particle size of $0.3 \mathrm{~mm}$ in a laboratory ball mill with uralite balls. The experimental data are presented in Table 7. 
Table 7. The matrix and results of the three-factor experiment.

\begin{tabular}{|c|c|c|c|c|c|c|c|}
\hline \multirow{2}{*}{ No. } & \multirow{2}{*}{$\begin{array}{c}\text { Temperature } \\
\text { of burning } \\
{ }^{\circ} \mathrm{C}\end{array}$} & \multicolumn{3}{|c|}{ Batch composition, \% } & Compressive & $\begin{array}{c}\text { Water } \\
\text { strength } \\
\text { absorption } \\
\mathrm{W}, \%\end{array}$ & $\begin{array}{c}\text { Density } \\
\mathrm{P}, \mathrm{g} / \mathrm{cm}^{3}\end{array}$ \\
\cline { 3 - 8 } & 900 & 85 & 10 & 5 & 28.4 & 18.5 & 1.54 \\
\hline 2 & 900 & 70 & 20 & 10 & 26.3 & 17.8 & 1.49 \\
\hline 3 & 900 & 55 & 30 & 15 & 24.6 & 17.5 & 1.45 \\
\hline 4 & 1,000 & 85 & 10 & 5 & 30.1 & 16.4 & 1.62 \\
\hline 5 & 1,000 & 70 & 20 & 10 & 28.9 & 15.7 & 1.57 \\
\hline 6 & 1,000 & 55 & 30 & 15 & 26.5 & 15.5 & 1.55 \\
\hline 7 & 1,100 & 85 & 10 & 5 & 31.3 & 13.1 & 1.76 \\
\hline 8 & 1,100 & 70 & 20 & 10 & 29.9 & 12.8 & 1.73 \\
\hline 9 & 1,100 & 55 & 30 & 15 & 29.2 & 12.3 & 1.69 \\
\hline
\end{tabular}

It can be seen from the table that the most optimal compounds are compounds No. 3, 6 and 9 that have the highest content of the industrial product $-30 \%$. The required sintering level of the raw material according to GOST 530-2012 is achieved with $15 \%$ cullet content.

By varying the maximum temperature of burning from 900 to $1,100{ }^{\circ} \mathrm{C}$, we produced a ceramic piece with different volumes of the pore structure, average density, $\mathrm{g} / \mathrm{cm}^{3},(1.45$, $1.55,1.69)$ and water absorption, $\%,(17.5,15.5,12.3)$.

\section{Conclusion}

As a result of the research, new knowledge of effects of slurries with high calcium content on physicochemical processes and the structure formation mechanism of a ceramic piece, properties of molding compounds, as well as physical and mechanical properties of ceramic products was gained.

Two-component batch compositions for the production of ceramic bricks based on a composition with low-quality local clay and drilling slurry using the semi-dry pressing method were developed. These raw materials ensure a high compaction degree of the molding compound, a homogeneous structure of the material throughout the production cycle, and making products with a strength grade M 100-150 that meet the requirements of [8].

The feasibility of introducing cullet additive ( $15 \%$ by weight) to the two-component batch and the possibility of producing a wide range of ceramics (porous wall ceramics, floor and roof tiles) on the basis of local low-quality clays in combination with a drilling slurry and flux were proven.

Thus, the obtained results will make it possible to fully adapt the production of ceramic bricks to the local raw material base, reduce the cost of bricks, to react quickly to market needs, and to improve the environmental situation in regions.

\section{References}

1. T.V. Vakalova, V.M. Pogrebenkov, Building materials, 5, 35 (2009) (in Russian)

2. S.P. Raut, R.V. Ralegaonkar, Construction and Building Materials, 5, 28 (2013) (in Russian) 
3. A. Benlalla, M. Elmoussaouiti, M. Dahhou M, Applied Clay Science, (2015)

4. V. Makarov, O. Suvorova, V. Kumarova, Proceedings of the XVI Balkan Mineral Processing Congress (Belgrade, Serbia, June 17-19, 2015)

5. A.Y. Stolboushkin, News of higher educational institutions. Construction (2015) (in Russian)

6. V. A. Mymrin, K. P. Alekseev., Construction and Building Materials, 5, 42 (2014) (in Russian)

7. V.V. Dubineckij, V.A. Guryeva, Building materials, 5, 40 ( 2015) (in Russian)

8. GOST 21216-2014 Raw clay. Test methods (2015) (in Russian)

9. GOST 530-2012 Ceramic brick and stone. General specifications (2013) (in Russian)

10. V.V. Dubineckij, V.A. Guryeva, K.M. Vdovin, Proceedings of the All-Russian Scientific and Practical Conference OSU,145, (2014) (in Russian)

11. A.L. Ukwatta, A. Mohajerani, Construction and Building Materials (2015)

12. V.A. Mymrin, R.E. Catai, A. Nagall, R.L. dos Santos Izzo, Applied Clay Science (2015)

13. R. Kusiorowski, T. Zaremba, J Construction and Building Materials (2016) 